\title{
ESPECTRORRADIOMETRIA NA IDENTIFICAÇÃO DE NÍVEIS DE DEGRADAÇÃO DE PASTAGEM CULTIVADA NA BACIA DO RIO SUBAÉ
}

\author{
$\underline{\text { Erli Pinto dos Santosi'; Taíse Bomfim de Jesus² }}$
}

1. Bolsista PIBIC/CNPq, graduando em Eng. Agronômica, Universidade Estadual de Feira de Santana, e-mail: erlitec.agri@outlook.com

2. Orientadora, Departamento de Ciências Exatas, Universidade Estadual de Feira de Santana, taisebj@hotmail.com Subaé

PALAVRAS-CHAVE: sensoriamento remoto, assinatura espectral, bacia do rio

\section{INTRODUÇÃO}

Os produtos da pecuária brasileira têm preço competitivo no mundo devido a característica dos sistemas semi-extensivos, e o baixo custo de produção nas pastagens. Francisco et al. (2017) diz que os sistemas de produção pecuária no Brasil apresentam grande diversidade, considerando-se que $45 \%$ e $55 \%$ são compostos de pastagens nativas e cultivadas, respectivamente, e que aproximadamente metade delas encontra-se em algum nível de degradação. A principal causa da degradação de pastagens é o empobrecimento do solo, em razão do esgotamento dos nutrientes perdidos no processo produtivo, por exportação para o corpo dos animais, erosão, lixiviação, volatilização, fixação e acúmulo nos malhadouros, e que não foram repostos ao longo de muitos anos de exploração (VASCONCELOS, 2006). Magnésio e nitrogênio são elementos que constituem o núcleo de porfirina de moléculas de clorofila. Para espécies nas quais o tecido de interesse econômico são as folhas, neste caso, são de extrema importância e sua falta logo provoca sintomas de deficiências (cloroses nas folhas). Logo, mesmo sendo uma planta jovem, se exposta a um ambiente com deficiência de magnésio e nitrogênio, haverá diminuição na concentração de clorofila e, consequentemente, menor absorção da energia luminosa (MOREIRA, 2005).

O uso de sistemas sensores, em nível de solo, para obter dados da radiação refletida e/ou emitida pelos alvos da superfície terrestre é sem dúvida, muito importante para entender o comportamento espectral desses alvos (MOREIRA, 2005). A espectrorradiometria é uma técnica de quantificação pontual de energia refletida por alvos de interesse, mensurando valores de reflectância em determinados comprimentos de onda. Os dados obtidos com análises espectrorradiométricas fornecem subsídios matemáticos para interpretação de imagens orbitais.

Assim o objetivo deste trabalho é de analisar as variáveis espectrais de pastagem em diferentes níveis de degradação, dentro da bacia do Rio Subaé, caracterizar os dados quanto a degradação, identificar níveis de degradação de pastagem a partir de técnicas de sensoriamento remoto e análises químicas e validar as metodologias de sensoriamento remoto citadas, comparando com a literatura existente, para análises em pastagens cultivadas.

\section{METODOLOGIA}

O ambiente de estudo foi escolhido trata-se de duas áreas de pastagem cultivadas com capim Brachiária decumbens no Centro de Agroecologia Rio Seco (CEARIS-UEFS), município de Amélia Rodrigues, um dos municípios cortados pela bacia do rio Subaé. Conforme descrição de Nascimento Júnior et al. (1994) para o gênero Brachiária, as pastagens estudadas foram classificadas em nível I com mais de $75 \%$ da área coberta pela gramínea forrageira e altura das plantas acima de $40 \mathrm{~cm}$, e a segunda área em estágio avançado de degradação, nível II, com 50 a $75 \%$ da área ocupada pela gramínea e a presença de plantas 
invasoras (imagens em anexo). A área I e área II possuem 858,53 e 1.023,1 m² respectivamente, conforme mapa de localização (Figura 1).

A amostragem para análises químicas seguiu adaptação da recomendação de Silva et al. (2009) para avaliação de deficiência nutricional no gênero Brachiária, amostrando 30 folhas/área, assim como para a coleta de dados radiométricos dos dosséis. A variável química escolhida foi clorofila total (clorofila-a + clorofila-b), e foi determinada em laboratório por extração com acetona 80\%, conforme metodologia de Arnon (1949), amplamente estabelecida na literatura.

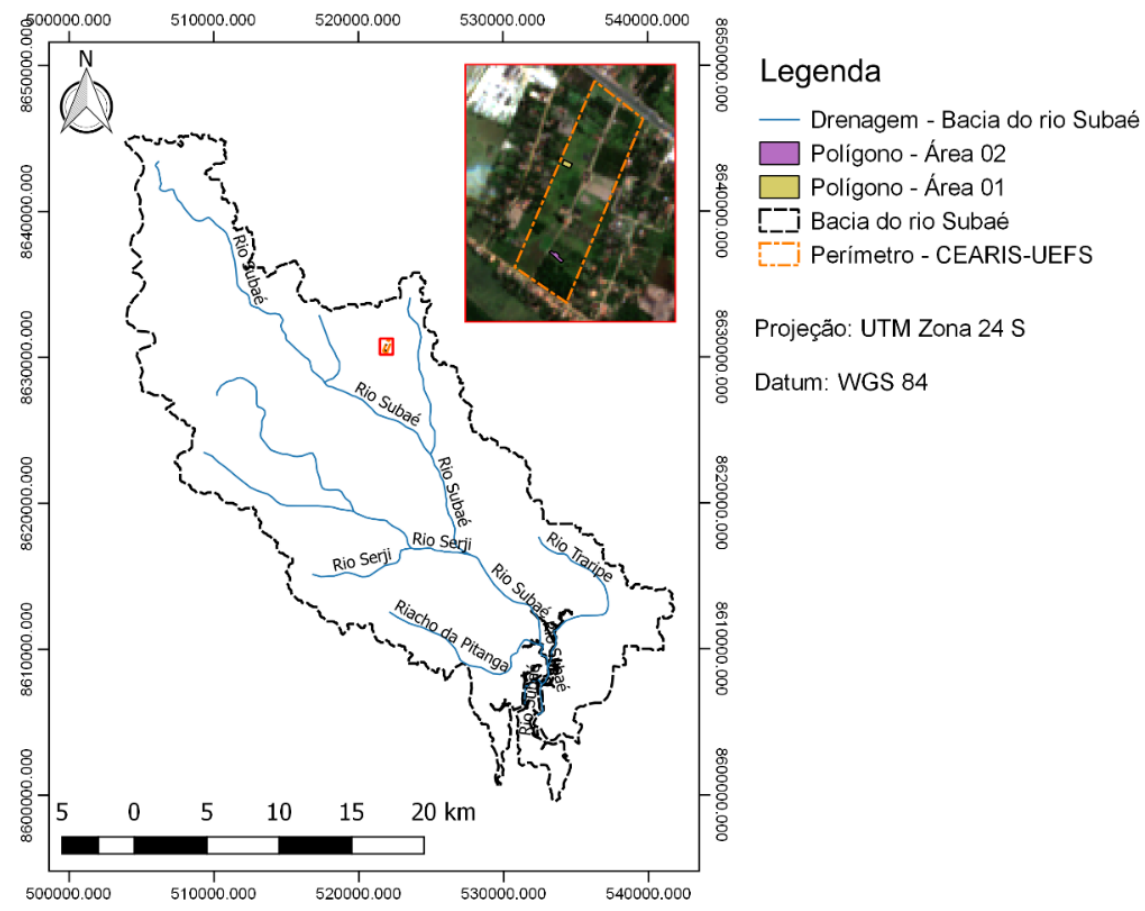

Figura 1: Carta de delimitação da bacia hidrográfica do rio Subaé, localizando a área de estudo na bacia.

O sensor utilizado para obtenção dos dados espectrorradiométricos em campo foi o espectrorradiômetro FieldSpec 4 Hi-Res (ASD Inc. - A PANalytical Company®), com faixa espectral de captação de sinal de 350 à $2500 \mathrm{~nm}$ com 2151 bandas do espectro eletromagnético, resolução de $3 \mathrm{~nm}$ até $700 \mathrm{~nm}$ e de $8 \mathrm{~nm}$ até 1400/2100. Os dados radiométricos das folhas de cada dossel foram coletados com a sonda Leaf Clip. O conjunto Leaf Clip da ASD foi projetado especificamente para uso com a sonda da planta para simplificar o processo de coleta de espectros sobre vegetação viva, no local do estudo. As coletas foram realizadas no período da manhã, entre 10:00 e 11:00.

\section{RESULTADOS E DISCUSSÕES}

A coleta de dados radiométricos em campo foi possível apenas nos meses de junho e julho de 2017, dados problemas associados as condições de tempo na região nos meses anteriores. A tabela 03 traz os resultados das análises de clorofila (a, b, e total) para os meses de junho e julho de 2017. Os valores de concentração de clorofila encontrados estão de acordo com as referências consultada, pois denotam deficiências nutricionais quanto mais se avança o estágio de degradação da pastagem.

Tabela 3: Concentrações de clorofila encontradas.

Mês jun/17 


\begin{tabular}{|l|l|l|l|l|}
\hline & Área I & Área II & Área I & Área II \\
\hline Clorofila-a $(\boldsymbol{\mu g} / \mathbf{g}$ MF) & 60,69104 & 37,54484 & 60,98332 & 35,0006 \\
\hline Clorofila-b $(\boldsymbol{\mu g} / \mathbf{g}$ MF) & 22,85472 & 6,40824 & 21,60776 & 9,44904 \\
\hline Total $(\boldsymbol{\mu g} / \mathbf{g}$ MF) & 83,52512 & 43,94384 & 82,57096 & 44,43944 \\
\hline
\end{tabular}

MF: Matéria fresca

Para plotagem das curvas espectrais, foi considerada a reflectância compreendida entre 400 e $900 \mathrm{~nm}$, região fotossinteticamente ativa. De maneira geral, os espectros apresentam características semelhantes, e esperadas para espécies vegetais, como a elevada reflectância na região do infravermelho próximo e baixa refletância na região do vermelho, que conforme Ponzoni e Shimabukuro (2009) exibem um comportamento antagônico característico. As curvas se assemelham aos resultados obtidos por PAZ et al. (2009) e ASSAD et al. (1991), para o gênero Brachiária, que analisaram respostas radiométricas de gramíneas forrageiras incluindo a espécie Brachiária decumbens (além de B. brizatha, B. humidicola, etc.). Os gráficos de reflectância estão dispostos na figura 02.
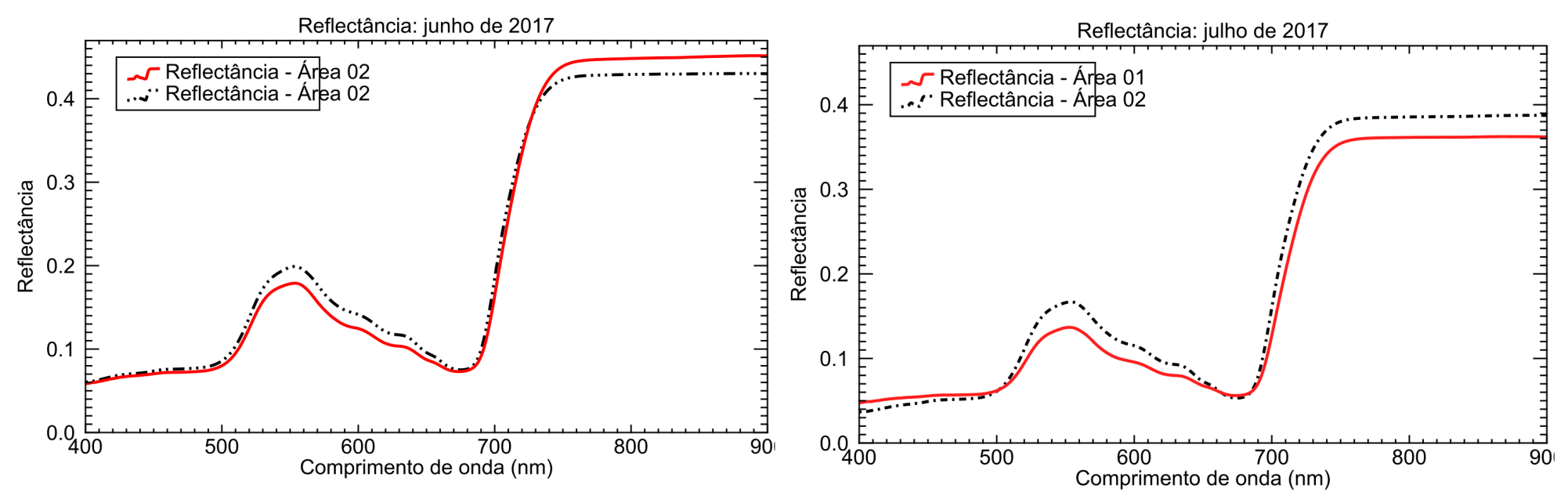

Figura 2: gráficos de reflectância do mês de junho (acima) e julho (abaixo) de 2017, da região fotossintéticamente ativa de 400 a $900 \mathrm{~nm}$.

Franco e Rosa (2004) analisaram níveis de degradação de pastagem Brachiária com espectrorradiometria de campo, entretanto empregando 4 bandas do satélite Landsat/TM: 450520; 520-600; 630-690; e 760-900 nm), compreendidas na região fotossinteticamente ativa. Os autores avaliaram mais níveis de degradação que neste trabalho, e evidenciaram que a uniformidade de uma pastagem de médio nível de degradação apresenta menor relação entre o infravermelho próximo e o vermelho. Também avaliam que na região do vermelho - região responsável pela ação dos pigmentos fotossintetizantes - a reflectância de uma pastagem degradada tende a ser maior que uma com menor nível de degradação, neste aspecto os gráficos da Figura 2 corroboram com o observado por Franco e Rosa (2004). Curran et al. (1990) tratam do comportamento de folhas verdes e respectivas conteúdo de clorofila mostrando que com o aumento da concentração de clorofila a reflectância diminui no visível (região do vermelho 550 a $720 \mathrm{~nm}$ ) e aumenta no infravermelho próximo, feição observada na curva do mês de junho/2017 para a área 01 onde a concentração de clorofila foi maior que na área 02.

Shul'gin e Keshnin (1959; apud Ponzoni e Shimabukuro, 2007) estudaram 80 espécies e verificaram que a absorção da energia radiante na região de $550 \mathrm{~nm}$ a $670 \mathrm{~nm}$ aumenta proporcionalmente com o aumento do conteúdo de clorofila. Considerando toda a banda de absorção, a área 02 com menor concentração de clorofila total nos meses de junho e julho/2017 apresentou maior reflectância nos espectros originais e nos gráficos de remoção do contínuo, 
nestes últimos (figura 3) exceto quanto mais se aproxima do centro da banda (em $665 \mathrm{~nm}$ ) onde se encontra a maior profundidade da banda; entretanto, nos gráficos de remoção do contínuo a proximidade entre as curvas é grande, ainda prevalecendo a área 02 com maior reflectância.

\section{CONSIDERAÇÕES FINAIS}

Skidmore et al. (2010) e Mutanga et al. (2004), estudaram a qualidade de pastagem por meio da espectrorradiometria de campo, com objetivo de identificar pastagens de melhor qualidade para animais, conseguindo diferenciar pastagem degradadas e até estimar conteúdo foliar. Franco e Rosa (2004) estudaram capim Brachiária e consideram que o monitoramento de pastagens muitas vezes é dificultado pelo manejo adotado pelos pecuaristas. Dessa forma os resultados do presente trabalho corroboram com os demais autores que tratam da espectrorradiometria como uma importante metodologia para estudos com esse tipo de vegetação, aplicando-se para a região em estudo, a bacia hidrográfica do Rio Subaé, sendo possível diferenciar os dois níveis de degradação estudados.

\section{REFERÊNCIAS BIBLIOGRÁFICAS}

VASCONCELOS, C. N. Pastagens: implantação e manejo. EBDA: Salvador, BA. 2006. 177p.

FRANCISCO, E. A. B.; BONFIM-SILVA, E. M.; TEIXEIRA, R. A. Aumento da produtividade de carne via adubação de pastagens. Informações Agronômicas. Piracicaba, p. 6-12. jun. 2017. Disponível em: < http://www.ipni.net/publication/ia-brasil.nsf/issue/IA-BRASIL-2017158? OpenDocument\&toc $=1>$. Acesso em: 03 jul. 2017.

NASCIMENTO JÚNIOR, D.; QUEIROZ, D. S.; SANTOS, M. V. Degradação das pastagens e critérios de avaliação. In: Anais do Simpósio sobre manejo da pastagem. 11., 1994. Piracicaba, SP. FEALQ, 1994. P. 107-152.

MOREIRA, M. A. Fundamentos do sensoriamento remoto e metodologias de aplicação. 3. ed. atualizada e ampliada. Viçosa. Editora UFV, 2005. 320p.

ARNON, D. I. Copper enzymes in isolated chloroplasts: polyphenoloxidase in Beta vulgaris. Plant Physiology, [s.i], v. 24, n. 1, p.01-15, jan. 1949.

SILVA, F. C. et al (Org.). Manual de análises químicas de solos, plantas e fertilizantes. 2. ed. Brasília: Embrapa, 2009. 627 p.

PAZ, C. R.; SAQUET, D. B.; FERRAZ, R. C.; GIROTTO, J.; PEREIRA, R. S.; COSTA, V. P. Discriminação de diferentes espécies de pastagens com uso da espectrorradiometria. In: SIMPÓSIO BRASILEIRO DE SENSORIAMENTO REMOTO, 14. (SBSR), 2009, Natal. Anais... São José dos Campos: INPE, 2009. p. 1175-1181.

CURRAN, P. J.; FOODY, G. M.; KONDRATYEV, K. Ya.; KOZODEROV, V. V.; FEDCHENKO, P. P. Remote sensing of soils and vegetation in the USSR. Ed. Taylor \& Francis, London; New York, 1990.

ASSAD, Eduardo D; MADEIRA NETO, José da Silva; MOREIRA, Lucimar. Uso de padrões radiométricos para separação de quatro espécies de gramíneas em condições de cerrado. Pesquisa Agropecuária Brasileira, Brasília, v. 26, n. 10, p.1625-1633, out. 1991.

FRANCO, José Benjamin Severino; ROSA, Roberto. Análise da possibilidade de identificar pastagens degradadas utilizando dados radiométricos de campo. Sociedade \& Natureza, Uberlândia, v. 16, n. 31, p.37-55, dez. 2004.

PONZONI, Flávio Jorge; SHIMABUKURO, Yosio Edemir. Sensoriamento remoto no estudo da vegetação. São José dos Campos: Parêntese, 2007. 135 p.

SKIDMORE, A. K. et al. Forage quality of savannas - Simultaneously mapping foliar protein and polyphenols for trees and grass using hyperspectral imagery. Remote Sensing Of Environment, [s.1.], v. 114, n. 1, p.64-72, jan. 2010. Elsevier BV. http://dx.doi.org/10.1016/j.rse.2009.08.010.

MUTANGA, O; SKIDMORE, A.k; PRINS, H.h.t. Predicting in situ pasture quality in the Kruger National Park, South Africa, using continuum-removed absorption features. Remote Sensing Of Environment, [s.1.], $\quad$ v. $\quad 89, \quad$ n. $3, \quad$ p.393-408, fev. 2004. Elsevier BV. http://dx.doi.org/10.1016/j.rse.2003.11.001. 